\title{
Serum progesterone levels on the day of hCG trigger and ICSI outcome: a retrospective observational cohort study
}

\author{
Kinnari Vilaschandra Amin ${ }^{1 *}$, Purnima Nadkarni², Pooja Nadkarni Singh³, Prabhakar Singh ${ }^{3}$
}

${ }^{1}$ IVF Department, ${ }^{2}$ Director, $21{ }^{\text {st }}$ Century Groups of Hospitals and Test Tube Baby Centre, Surat, Gujarat, India

${ }^{3} 21^{\text {st }}$ Century Hospitals and Test Tube Baby Centre and Nimaaya Women's centre for Health, Surat, Gujarat, India

Received: 21 May 2018

Accepted: 26 June 2018

*Correspondence:

Dr. Kinnari Vilaschandra Amin,

E-mail: kinnari.amin.127@gmail.com

Copyright: (c) the author(s), publisher and licensee Medip Academy. This is an open-access article distributed under the terms of the Creative Commons Attribution Non-Commercial License, which permits unrestricted non-commercial use, distribution, and reproduction in any medium, provided the original work is properly cited.

\begin{abstract}
Background: Whether serum progesterone $(\mathrm{P} 4)$ level on the day of human chorionic gonadotropin (hCG) trigger is related to the outcome of artificial reproductive technology (ART) is still a debatable issue. The objective of this study was to evaluate relationship between serum Progesterone levels on the day of hCG trigger and ICSI outcome.

Method: This was a retrospective, non-interventional, observational, cohort study of patients undergoing ICSI at $21^{\text {st }}$ Century Group of Hospitals, Killa Pardi and Surat, Gujarat during the period of January 2018 to March 2018. Patients with age group of 20-40 years who underwent ICSI-ET using GnRH antagonist flexible protocol during this period, had obtained 2 or more MII oocytes during retrieval and had at least one grade I embryo transferred were included in this study. Women using donor oocytes were excluded. Serum progesterone levels were analysed on day of hCG trigger. Total 165 patients were included in the study. They were divided into two groups, those with $\beta$-hCG less than or equal to $1.5 \mathrm{ng} / \mathrm{ml}$ and those with $\beta$-hCG more than $1.5 \mathrm{ng} / \mathrm{ml}$. Student's t test and Chi square test were used to compare the clinical pregnancy rates between two groups.

Results: Clinical pregnancy rate decreases with increase in serum progesterone levels on the day of hCG trigger. Patients with serum progesterone levels $\leq 1.5 \mathrm{ng} / \mathrm{ml}$ had significantly higher clinical pregnancy rates than those with progesterone levels $>1.5 \mathrm{ng} / \mathrm{ml}(45 \%$ vs $6 \%$; $\mathrm{p}:<0.001)$.

Conclusion: Pre-hCG rise in serum Progesterone concentration does not affect the oocyte quality. But, it significantly decreases the chances of implantation and the clinical pregnancy rates.
\end{abstract}

Keywords: hCG trigger, ICSI, Progesterone levels, Pregnancy

\section{INTRODUCTION}

Whether serum progesterone (P4) level on the day of human chorionic gonadotropin (hCG) trigger is related to the outcome of artificial reproductive technology (ART) is still a debatable issue. ${ }^{1-7}$

Few studies have shown no relationship between P4 elevation and clinical pregnancy rates, while others have shown negative impact of extremely elevated progesterone levels on clinical outcomes of in vitro fertilization (IVF). ${ }^{6-9,2-5,10-12}$

The mechanisms by which elevated $\mathrm{P} 4$ causes adverse effect on IVF outcomes remain unclear. According to some studies, $\mathrm{P} 4$ rise $(>1.5 \mathrm{ng} / \mathrm{ml})$ may have deleterious effects on endometrial receptivity. It causes acceleration of the endometrial maturation process that subsequently narrows the time frame for implantation and thus decreases the pregnancy rates. ${ }^{13,14}$ 
According to a recent systematic review, $\mathrm{P} 4$ elevation on the day of hCG administration is associated with a decreased chances of conception in fresh IVF cycles, however P4 elevation does not have an adverse effect during donor/recipient or frozen-thawed IVF cycles. ${ }^{2}$

A study suggested that day-5 blastocyst transfer may overcome the adverse effect of P4 elevation on the endometrium by providing sufficient time for the endometrium to recover from the detrimental effect of premature P4 elevation before transfer. ${ }^{15}$ However, two recent studies showed that $\mathrm{P} 4$ elevation on the day of hCG trigger has a negative impact on ART outcomes in blastocyst transfer cycles. ${ }^{1,16}$ The level of P4 elevation which can have a significant impact on ART outcomes remains unclear.

The main objective of this study was to determine the relationship between serum progesterone levels on the day of hCG administration and the clinical pregnancy rate.

\section{METHODS}

This was a retrospective, non-interventional, observational, cohort study of patients undergoing ICSI at $21^{\text {st }}$ Century Group of Hospitals, Killa Pardi and Surat, Gujrat during the period of January 2018 to March 2018.

Patients with age group of 20-40 years who underwent ICSI-ET using GnRH antagonist flexible protocol during this period, had obtained 2 or more MII oocytes during retrieval and had at least one grade I embryo transferred were included in this study. Total 165 patients were included in the study. They underwent controlled ovarian stimulation (COS) using GnRH antagonist flexible protocol. Stimulation was started from second day of menstrual cycle. Serum FSH, LH and estradiol levels were measured on second day of menstrual cycle. Stimulation was started using recombinant FSH. Follicular monitoring was done using transvaginal ultrasound.

Antagonist was added when leading follicle became 14 $\mathrm{mm}$ in size. Trigger was given when 3 or more follicles reached $17 \mathrm{~mm}$ in diameter. Trigger was given with either recombinant hCG alone or combination of recombinant $\mathrm{hCG}$ and agonist. On the day of trigger, serum LH, P4 and estradiol levels were measured. Oocyte retrieval was done 34-36 hours after trigger under transvaginal ultrasound guidance. ICSI was done then. Embryo transfer was done 48-72 hours later under ultrasound guidance. Embryos were further cultured till day 5 or 6 that is till blastocyst formation, in patients who had many embryos on day 2 or day 3 . Sequential transfer (blastocyst) was done on day 5 or day 6 in such cases. Luteal phase support was given to all cases.

First $\beta$-hCG was done 14 days after embryo transfer. Ten days later, transvaginal ultrasound was done. Clinical pregnancy was defined as the presence of at least one gestational sac with detectable cardiac activity by transvaginal sonography. The starting dose of gonadotropins was individualized for each patient according to age, BMI, antral follicle count, basal FSH and LH levels and previous response to COS. Dose adjustments were performed according to ovarian response.

\section{Exclusion criteria}

All those patients who opted for ovum donation or embryo donation were excluded from the study.

\section{Progesterone measurement}

Serum progesterone levels were measured on the day of hCG administration. Samples were tested with electrochemiluminescence immunoassay.

\section{Statistical analysis}

An elevated P4 level was arbitrarily defined as $1.5 \mathrm{ng} /$ $\mathrm{ml}$; this cut-off facilitated comparison with other reported data. This cutoff value is supported by the presence of marked difference in gene expression profile between patients with progesterone serum concentration above and below the threshold of $1.5 \mathrm{ng} / \mathrm{ml}$ on the day of hCG administration. ${ }^{17}$ Comparisons were made by Student's $t$ test and Chi square analysis where applicable. $\mathrm{P}<0.05$ was considered statistically significant.

\section{RESULTS}

The present study evaluated total 165 cases who underwent ICSI at our $21^{\text {st }}$ Century Group of Hospitals. Patients were classified according to the progesterone levels on the day of hCG trigger into two groups. Group A with Progesterone level of less than or equal to 1.5 $\mathrm{ng} / \mathrm{ml}$ and Group B with Progesterone level more than 1.5 $\mathrm{ng} / \mathrm{ml}$.

There were 143 patients in Group A and 22 patients in Group B. Both the groups were compared using student's $t$ test and chi square test. $p$ value of $<0.05$ was considered statistically significant.

Mean age of patients in Group A was 30.03 \pm 4.64 years and in Group B was $30.05 \pm 0.98$ years. Mean age in both the groups was comparable. There was no significant correlation between the age of the patients and progesterone level $(\mathrm{p}=0.98)$.

On the day of transfer, mean endometrial thickness of patients in Group A was $11.03 \pm 2.10 \mathrm{~mm}$ and that of patients in the Group B was $10.32 \pm 1.81 \mathrm{~mm}$. No statistically significant difference was found between two groups $(\mathrm{p}=0.14)$. 
The mean number of oocytes retrieved, and number of oocytes fertilized in Group A were 13.11 \pm 6.52 and $7.34 \pm 4.07$ respectively. Similarly, the mean number of oocytes retrieved, and number of oocytes fertilized in Group B were $15.20 \pm 7.10$ and $7.5 \pm 3.78$ respectively. Neither of them showed any significant correlation $(\mathrm{p}=$ 0.18 and $\mathrm{p}=0.87)$. Thus, both the groups were comparable to each other in terms of mean age, mean endometrial thickness on the day of transfer, number of oocytes retrieved, and number of oocytes fertilized. It suggests that the pre-hCG rise in $\mathrm{P} 4$ concentration does not affect the oocyte quality as there is no statistically significant difference in the number of oocyte retrieved and number of oocytes fertilized between the two groups (p: 0.18 and $\mathrm{p}: 0.87$ respectively).

Table 1: Correlation between Progesterone level on the day of hCG trigger and different parameters of the study.

\begin{tabular}{|c|c|c|c|}
\hline Parameters & Group A & Group B & P value \\
\hline Progesterone level & $\leq 1.5 \mathrm{ng} / \mathrm{ml}$ & $>1.5 \mathrm{ng} / \mathrm{ml}$ & \\
\hline No. cases & 143 & 22 & \\
\hline No. of cycles cancelled & 00 & 06 & $<0.0001$ \\
\hline Mean age & $30.03 \pm 4.64$ & $30.0 \pm 0.98$ & 0.98 \\
\hline Mean endometrial thickness on the day of transfer & $11.03 \pm 2.10$ & $10.32 \pm 1.81$ & 0.14 \\
\hline No. of oocytes retrieved & $13.11 \pm 6.52$ & $15.20 \pm 7.10$ & 0.18 \\
\hline No. of oocytes fertilized & $7.34 \pm 4.07$ & $7.5 \pm 3.78$ & 0.87 \\
\hline No. of cycles in which sequential transfer was done & $84 / 143$ & $7 / 16$ & $\mathrm{X}^{2}=1.32 \mathrm{p}=0.25$ \\
\hline \multirow{3}{*}{$\begin{array}{l}\text { In sequential transfer } \\
\text { In single transfer } \\
\text { Total }\end{array}$} & $42 / 84$ & $1 / 7$ & $\mathrm{X}^{2}=3.31 \mathrm{p}=0.068$ \\
\hline & $23 / 57$ & $0 / 9$ & $X^{2}=7.47 p=0.006$ \\
\hline & $65 / 143$ & $1 / 16$ & $\mathrm{X}^{2}=9.11 \mathrm{p}<0.001$ \\
\hline
\end{tabular}

$84(58.74 \%)$ patients out of total 143 in Group A had undergone sequential transfer, while $7(43.75 \%)$ patients out of total 16 from Group B had undergone sequential transfer. In case of sequential transfer, pregnancy rate in group A was 50\% (42/84) while in group B, it was $14 \%$ (1/7). But, it was not statistically significant (p: 0.068).

The pregnancy rate in group A was 45\% (65/143) while in group B, it was $6 \%(1 / 16)$. It is statistically significant as $\mathrm{p}$ value is $<0.001(\mathrm{p}<0.005)$. Hence, we can conclude that chances of clinical pregnancy rate are higher when the Progesterone level on the day of hCG trigger is $\leq 1.5$ $\mathrm{ng} / \mathrm{ml}$ in fresh transfer cycles.

\section{DISCUSSION}

$\mathrm{P} 4$ elevation on the day of hCG triggering is not rare in women undergoing IVF/ICSI. Pre-hCG elevation of P4 is poor predictor of IVF outcome. In our retrospective study, we have studied the relationship between P4 concentration on the day of trigger and clinical pregnancy rate in fresh embryo transfer cycles. The present study shows an adverse relationship between higher circulating serum concentrations of $\mathrm{P} 4$ with clinical pregnancy rate.

In a study conducted by Schoolcraft MD, the relationship of the circulating level of P4 on the day of hCG injection to occurrence of clinical pregnancy was examined in 133 leuprolide acetate human menopausal gonadotropin (hMG) in vitro fertilization cycles in women having at least three embryos transferred. ${ }^{18}$ Total 133 cycles were included in the study. Three groups were made depending on $\mathrm{P} 4$ concentration on the day of hCG trigger: those with
P4<0.5 ng/ml, between $0.5-0.9 \mathrm{ng} / \mathrm{ml}$ and $>0.9 \mathrm{ng} / \mathrm{ml}$. Pregnancy rate in first group was $54 \%$; in second group $24 \%$ and in third group $11 \%$. The clinical pregnancy rate decreased from $54 \%$ to $24 \%$ to $11 \%$ with increasing P4 concentrations. Because the rates in the two higher $\mathrm{P} 4$ groups were not statistically significantly different from one another, these two groups were combined for further analysis. Thus, the final conclusion was made that progesterone concentrations of $>0.5 \mathrm{ng} / \mathrm{mL}$ were associated with a significantly lower rate of pregnancy $(12 / 59,20 \%)$ compared with $<0.5 \mathrm{ng} / \mathrm{mL}(40 / 74,54 \%, \mathrm{P}$ $<0.005)$. This is similar to our study which also shows that clinical pregnancy rate decreases with increase in P4 concentration. But, the cutoff for P4 was taken as 1.5 $\mathrm{ng} / \mathrm{ml}$ instead of $0.5 \mathrm{ng} / \mathrm{ml}$.

A study was conducted by Fanchin to find out the effect premature elevation of plasma progesterone on pregnancy rates of in vitro fertilization and embryo transfer. ${ }^{19} 585$ consecutive IVF-ET cycles undertaken in 518 patients of 23 to 42 years of age were studied prospectively. These were divided into two groups according to plasma P4 levels observed on the day of $\mathrm{hCG}$ administration. Plasma P4 of $0.9 \mathrm{ng} / \mathrm{mL}(2.9 \mathrm{nmol} / \mathrm{L})$ was taken as an arbitrary cutoff value. Group A included 485 IVF cycles in which plasma $\mathrm{P} 4$ was $0.9 \mathrm{ng} / \mathrm{mL}$ (2.9 nmol/L); group B included the remaining 100 cycles in which plasma P4 was $>0.9 \mathrm{ng} / \mathrm{mL}(2.9 \mathrm{nmol} / \mathrm{L})$. The number of mature oocytes retrieved, the oocyte cleavage rate, and the number of embryos obtained were similar in two groups. Despite of this apparent similarity in oocyte quality, a decrease in pregnancy rate and a trend for a decrease in embryo implantation rate were observed in group $\mathrm{B}$ in 
comparison with group A. Thus, they concluded that prehCG elevation in plasma P4 does not lead to decreased oocyte quality but, it might alter endometrium receptivity to embryo implantation. These results are similar to our study in which the number of oocytes retrieved, and number of oocytes fertilized are similar in both the groups. Also, the clinical pregnancy rate is higher in group A with low P4 concentration on the day of hCG triggering ( $\mathrm{P} 4<1.5 \mathrm{ng} / \mathrm{ml})$ as compared to group $\mathrm{B}(\mathrm{P} 4$ $\geq 1.5 \mathrm{ng} / \mathrm{ml}$ ). But, the cut off for serum P4 in the present study is $1.5 \mathrm{ng} / \mathrm{ml}$.

A retrospective, observational, single-centre cohort study conducted by Bosch E evaluated the relationship between serum progesterone levels on the day of hCG triggering and the ongoing pregnancy rate in 4032 patients undergoing IVF/ICSI cycles using GnRH analogues for pituitary down-regulation. ${ }^{20}$ Ongoing pregnancy rates were inversely proportional to serum progesterone levels on the day of hCG ( $\mathrm{P}<0.001$ for overall trend), irrespective of the GnRH analogue used for pituitary down regulation. Similar to the present study, patients with serum progesterone levels $\leq 1.5 \mathrm{ng} / \mathrm{ml}$ had significantly higher ongoing pregnancy rates than those with progesterone levels $>1.5 \mathrm{ng} / \mathrm{ml}$ (31.0 versus $19.1 \%$; $\mathrm{P}=0.00006$. In the present study: $45 \%$ versus $6 \%$; $\leq 0.001)$.

Li M conducted a study to evaluate the effects of elevated serum progesterone level on the day of hCG injection on clinical outcome in IVF-ET patients. ${ }^{21} 655$ IVF-ET cycles were studied. The thresholds were set to 2.0 and $2.5 \mathrm{ng} / \mathrm{ml}$. The clinical pregnancy rate was lower in the elevated P4 group (41.6\% and 37.3\%) than in control $(46.3 \%$ and $46.0 \%)$, but the difference was not statistically significant $(p=0.197$ and $p=0.144)$. But in our study, this difference was statistically significant.

Swati G conducted a similar observational study to evaluate serum Progesterone levels on the day of hCG trigger and its relation to IVF/ICSI outcome. ${ }^{12} 120$ IVF/ICSI cycles were included in the study. Two study groups were made; group A with $\mathrm{P} 4 \leq 1.5 \mathrm{ng} / \mathrm{ml}$ and group B with P4 >1.5 ng/ml. Similar to the present study, cutoff of serum P4 was taken as $1.5 \mathrm{ng} / \mathrm{ml}$. Ongoing pregnancy rates were inversely proportional to serum progesterone levels on the day of hCG. Patients with serum progesterone levels $\leq 1.5 \mathrm{ng} / \mathrm{ml}$ had significantly higher ongoing pregnancy rates than those with progesterone levels $>1.5 \mathrm{ng} / \mathrm{ml}(46.6 \%$ vs. $17.24 \% ; \mathrm{p}=$ 0.028). These results are similar to the present study which shows higher pregnancy rate in patients with $\mathrm{P} 4$ $<1.5 \mathrm{ng} / \mathrm{ml}$ as compared to those with $\mathrm{P} 4 \geq 1.5 \mathrm{ng} / \mathrm{ml}$ ( $45 \%$ vs. $6 \% ; p \leq 0.001)$. Similar to the present study, this study demonstrates no deleterious effect of elevated $\mathrm{P} 4$ on embryo quality.

Larcher SJM conducted a study to determine the cut-off value of P4 levels on the day of hCG administration that are predictive of a subsequent decrease of the clinical pregnancy rate. ${ }^{11}$ Two cut-off values of serum P4 levels were found, 0.7 and $1.46 \mathrm{ng} / \mathrm{ml}$, dividing the population in three groups: Low $P$ levels: $<0.7 \mathrm{ng} / \mathrm{ml}\left(\mathrm{n}^{1} 1 / 414\right)$, Intermediate $\mathrm{P}$ levels : 0.7 to $1.46 \mathrm{ng} / \mathrm{ml}\left(\mathrm{n}^{1 / 425)}\right.$ and high P levels: $>1.46 \mathrm{ng} / \mathrm{ml}\left(\mathrm{n}^{1 / 415}\right)$. There was a significant difference in clinical pregnancy rates between patients from the groups of low, intermediate and high $\mathrm{P}$ serum levels $\left(71.4 \%, 48.0 \%\right.$ y $26.7 \%, \mathrm{p}^{1 / 4} 0.016 \mathrm{X} 2$ test for trend). That means pregnancy rate decreases with increase in serum P4 levels which is similar to the present study. But, the cutoff for P4 in the present study was taken as $1.5 \mathrm{ng} / \mathrm{ml}$.

\section{CONCLUSION}

Pre-hCG rise in serum Progesterone concentration does not affect the oocyte quality. But, it significantly decreases the chances of implantation and the clinical pregnancy rates. Hence, once the serum Progesterone crosses the critical level of $1.5 \mathrm{ng} / \mathrm{ml}$, it is prudent to do vitrification of all embryos and then transfer them in subsequent cycle.

\section{Funding: No funding sources}

Conflict of interest: None declared

Ethical approval: The study was approved by the Institutional Ethics Committee

\section{REFERENCES}

1. Corti L, Papaleo E, Pagliardini L, Rabellotti E, Molgora M, La Marca A, et al. Fresh blastocyst transfer as a clinical approach to overcome the detrimental effect of progesterone elevation at hCG triggering: a strategy in the context of the Italian law. Eur J Obstet Gynecol Reprod Biol. 2013;171:73-7.

2. Venetis CA, Kolibianakis EM, Bosdou JK, Tarlatzis BC. Progesterone elevation and probability of pregnancy after IVF: a systematic review and metaanalysis of over 60000 cycles. Hum Reprod Update. 2013;19:433-57.

3. Xu B, Li Z, Zhang H, Jin L, Li Y, Ai J, et al. Serum progesterone level effects on the outcome of in vitro fertilization in patients with different ovarian response: an analysis of more than 10,000 cycles. Fertil Steril. 2012;97:1321-7.

4. Elgindy EA. Progesterone level and progesterone/estradiol ratio on the day of $\mathrm{hCG}$ administration: detrimental cutoff levels and new treatment strategy. Fertil Steril. 2011;95:1639-44.

5. Kilicdag EB, Haydardedeoglu B, Cok $T$, Hacivelioglu SO, Bagis T. Premature progesterone elevation impairs implantation and live birth rates in GnRH agonist IVF/ICSI cycles. Arch Gynecol Obstet. 2010;281:747-52.

6. Venetis CA, Kolibianakis EM, Papanikolaou E, Bontis J, Devroey P, Tarlatzis BC. Is progesterone elevation on the day of human chorionic gonadotrophin administration associated with the probability of pregnancy in in vitro fertilization? A 
systematic review and meta-analysis. Hum Reprod Update. 2007;13:343-55.

7. Martinez F, Coroleu B, Clua E, Tur R, Buxaderas R, Parera N, et al. Serum progesterone concentrations on the day of HCG administration cannot predict pregnancy in assisted reproduction cycles. Reprod Biomed Online. 2004;8:183-90.

8. Houmard BS, Ball D, Soules MR. Elevated serum progesterone levels on the day of trigger do not adversely affect pregnancy rates: a prospective blinded evaluation in 384 consecutive IVF cycles. Fertil Steril. 2014;101:e10-11.

9. Gunderson S, Anderson K, Riley J. Progesterone value on day of HCG trigger is not associated with outcomes from fresh embryo transfer. Fertil Steril. 2018;109:e29-30.

10. Tsai, Yi-Ru. Progesterone elevation on the day of human chorionic gonadotropin administration is not the only factor determining outcomes of in vitro fertilization. Fertil Steril. 2015;103:106-11.

11. Larcher SJM, Ganzer LM, Maccari VM. Clinical pregnancy rates according to the serum progesterone level on the human chorionic gonadotropin day. Fertil Steril. 2016;106:e200.

12. Swati G, Surbhi TS, Deepa LM. Progestrone level on the day of hCG trigger and IVF outcomes: an observational study. IJBAMR. 2016;6(1):682-6.

13. Kasum M, Radakovic B, Simunic V, Oreškovic S. Preovulatory progesterone rise during ovarian stimulation for IVF. Gynecol Endocrinol. 2013;29(8):744-8.

14. Haouzi D, Bissonnette L. Endometrial receptivity profile in patients with premature progesterone elevation on the day of hCG administration. BioMed Res Int. 2014;2014.

15. Papanikolaou EG, Kolibianakis EM, Pozzobon C, Tank P, Tournaye H, Bourgain C, et al. Progesterone rise on the day of human chorionic gonadotropin administration impairs pregnancy outcome in day 3 single-embryo transfer, while has no effect on day 5 single blastocyst transfer. Fertil Steril. 2009;91:94952 .
16. Ochsenkuhn R, Arzberger A, von Schonfeldt V, Gallwas J, Rogenhofer N, Crispin A, et al. Subtle progesterone rise on the day of human chorionic gonadotropin administration is associated with lower live birth rates in women undergoing assisted reproductive technology: a retrospective study with 2,555 fresh embryo transfers. Fertil Steril. 2012;98:347-54.

17. Vaerenbergh VI, Fatemi HM, Blockeel C. Progesterone rise on $\mathrm{HCG}$ day in $\mathrm{GnRH}$ antagonist/rFSH stimulated cycles affects endometrial gene expression. Reprod Biomed Online. 2011;22(3):263-71.

18. Schoolcraft W, Sinton, E, Schlenker, T, Huynh, D, Hamilton F, Meldrum, D. Lower pregnancy rate with premature luteinization during pituitary suppression with leuprolide acetate. Fertil Steril. 1991;55:563-6.

19. Fanchin R, de Zeigler D, Taieb J, Hazout A, Frydman R. Premature elevation of plasma progesterone alters pregnancy rates of in vitro fertilization and embryo transfer. Fertil Steril. 1993;59:1090-4.

20. Bosch E, Labarta E, Crespo J, Simón C, Remohí J, Jenkins $\mathbf{J}$, et al. Circulating progesterone levels and ongoing pregnancy rates in controlled ovarian stimulation cycles for in vitro fertilization: analysis of over 4000 cycles. Hum Reprod. 2010;25(8):2092100.

21. Li M, Xie Y, Park H, Kumar A, Hubert G, Buyalos $R$. The effects of elevated serum progesterone level at the day of hCG injection on clinical outcome in IVF-ET patients. Fertil Steril. 2013;100(3):S7.

Cite this article as: Amin KV, Nadkarni P, Singh PN, Singh P. Serum progesterone levels on the day of hCG trigger and ICSI outcome: a retrospective observational cohort study. Int J Reprod Contracept Obstet Gynecol 2018;7:3194-8. 